Supporting Information (SI)

\title{
CD147 Monoclonal Antibody Targeted \\ Reduction-Responsive Camptothecin Polyphosphoester Nanomedicine for Drug Delivery in Hepatocellular Carcinoma Cells
}

\author{
Hongrui Tian, Yakui Huang, Jinlin He, Mingzu Zhang, Peihong Ni* \\ College of Chemistry, Chemical Engineering and Materials Science, State and Local Joint Engineering Laboratory for Novel Functional \\ Polymeric Materials, Jiangsu Key Laboratory of Advanced Functional Polymer Design and Application, Suzhou Key Laboratory of \\ Macromolecular Design and Precision Synthesis, Soochow University, Suzhou 215123, People’s Republic of China
}

* To whom correspondence should be addressed. Peihong Ni (E-mail: phni@ suda.edu.cn). 


\section{Experimental section}

Materials. The following agents were not further purified when used: $\mathrm{HO}-\mathrm{PEG}-\mathrm{NH}_{2} \cdot \mathrm{HCl}$ $\left(\bar{M}_{\mathrm{n}}=3400 \mathrm{~g} \mathrm{~mol}^{-1}\right.$, Shanghai Ponsure Biotech, Inc.), diethyl squarate (SADE, 98\%, Energy Chemical), triethylamine (TEA, AR, Enox), acetic acid (AcOH, AR, Enox), 1,8-diazabicyclo[5.4.0]undec-7-ene (DBU, 98\%, TCI), Camptothecin (CPT, 99\%, Beijing Zhongshuo Pharmaceutical Technology Development), 2,2'-dithiodiethanol (TP, Sigma-Aldrich), 2-bromo-2-methylpropionylbromide (98\%, Sigma-Aldrich), 4-dimethylaminopyridine (DMAP, 99\%, J\&K), bis (trichloromethyl) carbonate (BTC, 99\%, J\&K), sodium azide (AR, Sinopharm Chemical Reagent), $N, N, N N^{\prime}, N$ ", $N$ '-pentamethyl diethylenetriamine (PMDETA, 98\%, Sigma-Aldrich), 3-(4,5-dimethylthiazol-2-yl)-2,5-diphenyl tetrazolium bromide (MTT, 98\%, Sigma-Aldrich) glutathione (GSH, 99\% Shanghai Yuanye Bio-Technology Co., Ltd) and Lyso-Tracker Red (Solarbio) and dulbecco's modified eagle medium (DMEM) (HyClone). Milli-Q water $\left(18.2 \mathrm{M} \Omega \mathrm{cm}\right.$ at $\left.25^{\circ} \mathrm{C}\right)$ was produced through a water purification system (Simplicity UV, Millipore). Dichloromethane $\left(\mathrm{CH}_{2} \mathrm{Cl}_{2}\right)$ was dried and refluxed with $\mathrm{CaH}_{2}$ before use. $N$, $N$-Dimethylformamide (DMF) was dried over sodium sulfate anhydrous $\left(\mathrm{Na}_{2} \mathrm{SO}_{4}, 99 \%\right.$, Enox) for $24 \mathrm{~h}$ and distilled before use. 2-(But-3-yn-1-yloxy)-2-oxo-1,3,2-dioxaphospholane (BYP) was prepared and purified according to the literature. ${ }^{\mathrm{S} 1}$

\section{Synthesis of reduction-responsive camptothecin derivative (CPT-ss- $\left.\mathrm{N}_{3}\right)$}

The reduction-responsive camptothecin derivative CPT-ss- $\mathrm{N}_{3}$ was prepared and purified according to literature. ${ }^{\mathrm{S} 2}$ Firstly, 2,2'-dithiobis[1-(2-bromo-2-methylpropionyloxy) ethane] (HO-ss-Br) was prepared by monoesterfication. Succinctly, 2-bromo-2-methylpropionyl bromide (5.2 g, $22.6 \mathrm{mmol})$ was added dropwise to a mixture of the 2,2'-dithiodiethanol (5.3 g, $34.4 \mathrm{mmol})$ and triethylamine $(2.5 \mathrm{~g}, 24.7 \mathrm{mmol})$ in $100 \mathrm{~mL}$ of anhydrous THF under nitrogen atmosphere. The mixture was stirred at $0{ }^{\circ} \mathrm{C}$ for $1 \mathrm{~h}$ and then for another $12 \mathrm{~h}$ at $35{ }^{\circ} \mathrm{C}$. After filtration, the solvent was rotary evaporated and dissolved using $100 \mathrm{~mL} \mathrm{CH}_{2} \mathrm{Cl}_{2}$. The solution extracted with 30 $\mathrm{mL} 1.0 \mathrm{M} \mathrm{HCl}$ and saturated sodium chloride for twice, respectively. The organic phase was collected and dried with anhydrous $\mathrm{Na}_{2} \mathrm{SO}_{4}$ for $4 \mathrm{~h}$. Finally, after concentrating the filtrate, it was further separated and purified by silica gel column chromatography using ethyl 
acetate/dichloromethane $(5 / 1, v / v)$ as the eluent. (HO-ss-Br, yield: $56.6 \%)$.

HO-ss- $\mathrm{Br}(3.1 \mathrm{~g}, 10.2 \mathrm{mmol})$ and $\mathrm{NaN}_{3}(2.1 \mathrm{~g}, 32.3 \mathrm{mmol})$ were added to a $50 \mathrm{~mL}$ round-bottom flask containing $15 \mathrm{~mL}$ of DMF. The reaction was stirred at $30^{\circ} \mathrm{C}$ for $24 \mathrm{~h}$. After filtration and rotary evaporated, the mixture was dissolved using $100 \mathrm{~mL} \mathrm{CH}_{2} \mathrm{Cl}_{2}$ and extracted with $30 \mathrm{~mL}$ saturated sodium chloride for three times. The organic layer was dried over anhydrous $\mathrm{Na}_{2} \mathrm{SO}_{4}$ for $4 \mathrm{~h}$. After concentrating the filtrate, the product was dried to constant weight in vacuum oven. (HO-ss- $\mathrm{N}_{3}$, yield: 79.2\%).

Finally, CPT (1.5 g, $4.31 \mathrm{mmol})$, DMAP (1.59 g, $12.9 \mathrm{mmol})$ and triphosgene $(0.43 \mathrm{~g}, 1.45$ mmol) were suspended in $50 \mathrm{~mL}$ of dry $\mathrm{CH}_{2} \mathrm{Cl}_{2}$ under nitrogen atmosphere. And the mixture was stirred at $25{ }^{\circ} \mathrm{C}$ for $1 \mathrm{~h}$. After that, a solution of HO-ss- $\mathrm{N}_{3}(1.13 \mathrm{~g}, 4.26 \mathrm{mmol})$ in $15 \mathrm{~mL}$ of dry $\mathrm{CH}_{2} \mathrm{Cl}_{2}$ was added dropwise into the mixture through a constant pressure funnel. The reaction was further stirred at $25{ }^{\circ} \mathrm{C}$ for $12 \mathrm{~h}$. After concentrating the filtrate, the solution extracted with $1.0 \mathrm{M}$ $\mathrm{HCl}$ and saturated sodium chloride for twice, respectively. The organic phase was dried with anhydrous $\mathrm{Na}_{2} \mathrm{SO}_{4}$ for $4 \mathrm{~h}$. Finally, after concentrating the filtrate, it was further separated and purified by silica gel column chromatography using ethyl acetate as the eluent. (CPT-ss- $\mathrm{N}_{3}$, yield: $56.6 \%)$.

\section{Synthesis of SAE-PEG-OH}

Briefly, SAE-PEG-OH was synthesized by dropwise adding $8 \mathrm{~mL}$ an aqueous solution of HO-PEG-NH ${ }_{2} \cdot \mathrm{HCl}(0.51 \mathrm{~g}, 0.15 \mathrm{mmol})$ and triethylamine $(0.15 \mathrm{~g}, 1.5 \mathrm{mmol})$ into an ethanol solution of diethyl square acid $(0.51 \mathrm{~g}, 3.0 \mathrm{mmol})$ at $0{ }^{\circ} \mathrm{C}$ followed by stirring at $35{ }^{\circ} \mathrm{C}$ for $24 \mathrm{~h}$. Then the raw product was dialyzed (MWCO $1000 \mathrm{Da}$ ) against ethanol for $8 \mathrm{~h}$ and Milli-Q water for $24 \mathrm{~h}$. The final product was obtained by lyophilization. (SAE-PEG-OH, yield: $65.2 \%$ ).

\section{Synthesis of the reduction-responsive prodrug SAE-PEG-b-PBYP-ss-CPT}

The reduction-responsive prodrug SAE-PEG- $b$-PBYP ${ }_{51}-s s-\mathrm{CPT}$ was synthesized via the $\mathrm{Cu}(\mathrm{I})$-catalyzed azide-alkyne cycloaddition (CuAAC) reaction. Briefly, SAE-PEG- $b$-PBYP ${ }_{51}(0.18$ $\mathrm{g}, 0.014 \mathrm{mmol})$, CPT-ss- $\mathrm{N}_{3}(99.8 \mathrm{mg}, 0.15 \mathrm{mmol})$ and $10 \mathrm{~mL}$ of anhydrous DMF were added in a $25 \mathrm{~mL}$ branch flask, and stirring the resulting mixture until homogeneous. Simultaneously, $\mathrm{CuBr}$ (43.0 $\mathrm{mg}, 0.30 \mathrm{mmol}$ ) and PMDETA $(103.9 \mathrm{mg}, 0.60 \mathrm{mmol}$ ) were added under nitrogen atmosphere, and then perform 3 cycles of exhaust-nitrogen refilling. The reaction was stirred at $35^{\circ} \mathrm{C}$ for $24 \mathrm{~h}$. Then the mixture was dialyzed (MWCO $7000 \mathrm{Da}$ ) against DMF for $8 \mathrm{~h}$ to remove 
unreacted CPT-ss- $\mathrm{N}_{3}$ and Milli-Q water for $48 \mathrm{~h}$. Finally, the brown solid product was collected by lyophilization. (SAE-PEG-b-PBYP ${ }_{51}-s s-\mathrm{CPT}$, yield: 71.3\%).

\section{Measurement of critical aggregation concentration (CAC)}

We tested the critical aggregation concentration (CAC) of SAE-PEG- $b$-PBYP ${ }_{51}-s s-\mathrm{CPT}$ using the pyrene fluorescent probe method. ${ }^{\mathrm{S}, \mathrm{S} 4} 50 \mathrm{uL}$ of pyrene $\left(0.594 \mathrm{~mol} \mathrm{~L}^{-1}\right)$ in acetone was added to a series of saline bottles, and the acetone was removed under reduced pressure with a water pump. Subsequently, a series of polymeric prodrug solutions of different concentrations were prepared in the saline bottle, and the total volume in each saline bottle was $5 \mathrm{~mL}$. The mixture was sonicated for $30 \mathrm{~min}$ and stirred vigorously for $48 \mathrm{~h}$. The solutions were measured with a fluorescence spectrophotometer. Excitation wavelength was $335 \mathrm{~nm}$ and emission spectra recording range were from $350 \mathrm{~nm}$ to $550 \mathrm{~nm}$ with $5 \mathrm{~nm}$ slit width. From the emission spectra, the intensity ratio $\left(I_{3} / I_{1}\right)$ of the third bond $\left(383 \mathrm{~nm}, I_{3}\right)$ to the first bond $\left(372 \mathrm{~nm}, I_{1}\right)$ was analyzed as the function of the logarithm concentration of the copolymer solution. The CAC value was dependent on the intersection of the two lines in the plot of intensity ratio $\left(I_{3} / I_{1}\right)$ versus the copolymer concentration.

\section{Self-assembly behavior of SAE-PEG- $b$-PBYP-ss-CPT prodrug nanoparticles}

The average particle sizes $\left(\bar{D}_{\imath}\right)$, size polydispersity index (size PDI) and morphologies of CPT-loaded NPs and CD147-CPT NPs were respectively investigated by dynamic light scattering (DLS) detector (Zetasizer Nano ZS, Malver) and transmission electron microscope (TEM) instrument (HT7700, Hitachi) operated at $120 \mathrm{kV}$. In brief, $25 \mathrm{mg}$ sample was dissolved in $25 \mathrm{~mL}$ deionized water by ultrasound at room temperature for $4 \mathrm{~h}$. The concentrations of nanoparticles were kept at $1 \mathrm{mg} \mathrm{mL}^{-1}$. TEM samples were obtained by freeze-drying method. The sample solution was added to the carbon coated copper mesh frozen in liquid nitrogen and the solvent was directly lyophilized by the lyophilizer.

\section{Enzyme degradation of polyphosphoester backbone}

The ability of polymers as drug carriers to degrade in vivo is important. In order to verify the enzymatic degradation performance of polyphosphoester backbone, ${ }^{1} \mathrm{H}$ NMR was used to test the degradation products of phosphodiesterase I (PDE I) in the presence of different time. Briefly, a pre-weighed $20 \mathrm{mg}$ SAE-PEG- $b$-PBYP ${ }_{51}$, dissolved in $10 \mathrm{~mL} \mathrm{~PB} 7.4$ buffer solution, with PDE I (5 mg) and $\mathrm{MgCl}_{2} \cdot 6 \mathrm{H}_{2} \mathrm{O}$ (50 mg). After sufficient dissolution, they were placed in a constant temperature shaker at $37^{\circ} \mathrm{C}$, and a point was taken every $24 \mathrm{~h}$, freeze-dried, and the results were 
analyzed by ${ }^{1} \mathrm{H}$ NMR.

\section{In vitro CPT release from SAE-PEG- $b$-PBYP-ss-CPT}

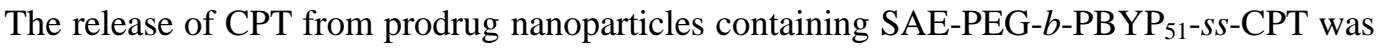
investigated in phosphate buffer solution under different conditions: phosphate buffer solution $(0.1$ M, PB 7.4), phosphate buffer solution with $10 \mathrm{mM}$ GSH. First, $30 \mathrm{mg}$ of SAE-PEG- $b$-PBYP ${ }_{51}-s s$-CPT prodrug was dissolved with $30 \mathrm{~mL}$ phosphate buffer solution $(0.1 \mathrm{M}$, PB 7.4) and stirred for $4 \mathrm{~h}$. Then the prepared prodrug nanoparticles $(5 \mathrm{~mL})$ were moved to a dialysis bag (MWCO $7000 \mathrm{Da}$ ) and put into a series of tubes with $40 \mathrm{~mL}$ phosphate buffer. These tubes were placed into a constant temperature shaker at $37^{\circ} \mathrm{C}$. At a set time, $5 \mathrm{~mL}$ of the solution was taken out and stored in centrifuge tubes, and then an equal volume of fresh buffer was added. The concentration of released CPT was tested with a fluorescence spectrophotometer (Cary Eclipse, Agilent Technologies) under the conditions of an excitation wavelength of $365 \mathrm{~nm}$, an emission wavelength of 390-550 nm, and a slit width of $5 \mathrm{~nm}$.

\section{In vitro cytotoxicity test}

The cytotoxicity of the diblock copolymer (SAE-PEG- $b$-PBYP F1 $_{5}$, polymeric prodrug (CPT-loaded NPs), and monoclonal antibody-conjugated nanoparticles (CD147-CPT NPs) were evaluated by MTT assays. HUVEC cells, HepG2 cells and Hela cells were cultured in $100 \mu \mathrm{L}$ high glucose DMEM medium at a density of $5 \times 10^{4}$ cells/well in a 96-well culture plate for $12 \mathrm{~h}$, and subjected to different treatments to analyze cell proliferation. Then $25 \mu \mathrm{L}$ of the samples were added in the wells with different concentrations, respectively, and the same volume of PBS solutions were added as control groups. Cells were incubated in the presence of equivalent CPT concentrations from 0.05 to $25 \mathrm{mg} \mathrm{L}^{-1}$ for $48 \mathrm{~h}$. Then $25 \mu \mathrm{L}$ of MTT (5 mg mL $\mathrm{m}^{-1}$ in PBS) solutions were added in the well and further incubated at $37{ }^{\circ} \mathrm{C}$ for $4 \mathrm{~h}$. And then solutions were removed in the plate and $150 \mu \mathrm{L}$ of DMSO was added in each well to absolutely dissolve the formazan. Finally, the optical density (OD) values were examined at an absorbance of $570 \mathrm{~nm}$ by a Microplate reader (Bio-Rad 680, USA).

The cell viability (\%) was calculated by the following formula:

$$
\text { Cell Viability }(\%)=\frac{\mathrm{OD}_{\text {sample }}}{\mathrm{OD}_{\text {control }}} \times 100
$$

where $\mathrm{OD}_{\text {sample }}$ and $\mathrm{OD}_{\text {control }}$ represent the $\mathrm{OD}$ values of the sample wells and the control wells 
treated with PBS.

\section{Measurement of the cellular uptake}

The cellular uptake and intracellular release in HepG2 cells of free CPT, CPT-loaded NPs and CD147-CPT NPs were investigated by a live cell imaging system (CELL'R, Olympus). Briefly, cells were loaded in an $\Phi 20 \mathrm{~mm}$ glass bottom cell culture dish at a density of $2 \times 10^{5}$ cells per dish and incubated overnight. And then the culture medium was removed and replaced by the fresh medium with Lyso-Tracker Red $\left(100 \mu \mathrm{L} \mathrm{L}^{-1}\right)$, cultured for 40 min, then washing with PBS 3 times. Finally, the medium involving 10\% CPT-loaded NPs, CD147-CPT NPs or free CPT were added with the same CPT content $\left(13.18 \mathrm{mg} \mathrm{L}^{-1}\right)$, respectively.

\section{Statistical analysis}

All data in this paper were presented as means \pm standard deviation. All the statistical analyses were performed using the student's t-test. Differences were considered statistically significant at a level of $* p<0.05$, and very significant when ${ }^{* *} p<0.01$ and $* * * p<0.001$.

\section{Characterization}

The polymer structures were characterized by ${ }^{1} \mathrm{H}$ nuclear magnetic resonance spectroscopy ( ${ }^{1} \mathrm{H}$ NMR) (INOVA-400) using $\mathrm{CDCl}_{3}$ and DMSO- $d_{6}$ as the solvents and tetramethylsilane (TMS) as internal reference. Relative molecular weight $\left(\bar{M}_{\mathrm{n}}\right)$ and dispersity $(\nexists)$ of SAE-PEG- $b$-PBYP were analyzed by gel permeation chromatography (GPC) instrument (HLC-8320, Tosoh) using polystyrene as the standard and DMF as the eluent. Fourier transform infrared (FT-IR) spectra were recorded on a Bruker TENSOR-27 FT-IR spectrometer using the $\mathrm{KBr}$ disk method. The structure of camptothecin derivative and polymeric prodrugs were analyzed by high performance liquid chromatography (HPLC) and ultraviolet-visible absorption spectroscopy (UV-vis).

\section{Cell culture}

HUVEC cells (human umbilical vein endothelial cells), HepG2 cells (human hepatocellular carcinoma cells) and Hela cells (human cervical cancer cells) obtained from American Type Culture Collection (ATCC) and were cultured in high glucose DMEM with $10 \%$ fetal bovine serum (FBS) and 1\% penicillin/streptomycin solution. Both cells were passaged once every 2 days and incubated at $37{ }^{\circ} \mathrm{C}$ in an atmosphere containing $5 \% \mathrm{CO}_{2}$. 


\section{Part I. List of Figure Captions}

Figure S1. ${ }^{1} \mathrm{H}$ NMR spectra of (A) HO-ss-Br, (B) HO-ss- $\mathrm{N}_{3}$ in $\mathrm{CDCl}_{3}$ and (C) CPT-ss- $\mathrm{N}_{3}$ in DMSO- $d_{6}$.

Figure S2. FT-IR spectra of (A) HO-ss-Br, (B) HO-ss- $\mathrm{N}_{3}$ and (C) CPT- $s s-\mathrm{N}_{3}$.

Figure S3. MALDI-TOF MS spectrum of SAE-PEG-OH.

Figure S4. GPC curves of (A) SAE-PEG-OH $\left(\bar{M}_{\mathrm{n}}=3400 \mathrm{~g} \mathrm{~mol}^{-1}, \mathrm{PDI}=1.22\right)$ and (B) SAE-PEG- $b$-PBYP ${ }_{51}\left(\bar{M}_{\mathrm{n}}=10500 \mathrm{~g} \mathrm{~mol}^{-1}, \mathrm{PDI}=1.49\right)$ in DMF.

Figure S5. HPLC analyses results of (A) free CPT, (B) CPT-ss- $\mathrm{N}_{3}$ and (C) SAE-PEG- $b$-PBYP ${ }_{51}-s s$-CPT. HPLC analyses were performed with acetonitrile-water $(75 / 25, v / v)$ as the mobile phase at $30{ }^{\circ} \mathrm{C}$ with a flow rate of $1.0 \mathrm{~mL} \mathrm{~min}^{-1}$.

Figure S6. UV-vis spectra of free CPT, SAE-PEG- $b$-PBYP-ss-CPT and SAE-PEG- $b$-PBYP.

Figure S7 Intensity ratios $\left(I_{3} / I_{1}\right)$ in fluorescence emission spectra of pyrene as a function of logarithm concentration of SAE-PEG- $b$-PBYP S1- $-s s-C P T$ in aqueous solution.

Figure S8. HPLC analyses results of (A) free CPT, (B) CPT-ss $-\mathrm{N}_{3}$, (C) CPT-ss- $\mathrm{N}_{3}$ with $10 \mathrm{mM}$ GSH, (D) SAE-PEG- $b$-PBYP $51-s s$-CPT and (E) SAE-PEG- $b$-PBYP P1- $s s-C P T$ with $10 \mathrm{mM} \mathrm{GSH}$. HPLC analyses were performed with acetonitrile-water $(75 / 25, v / v)$ as the mobile phase at $30{ }^{\circ} \mathrm{C}$

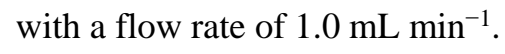


Part II. Figures for Various Measurements

(A)

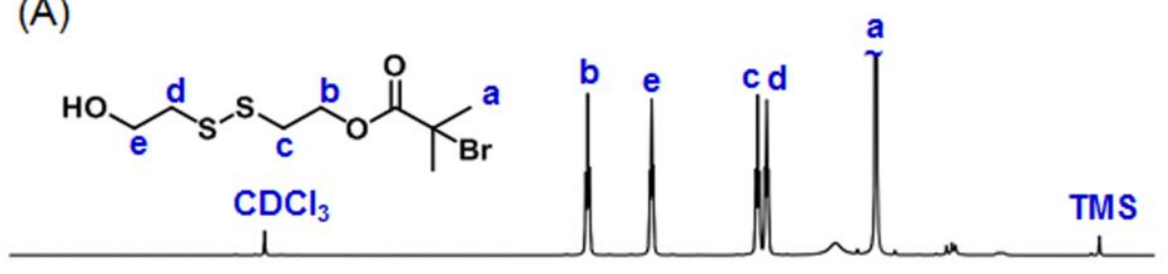

(B)
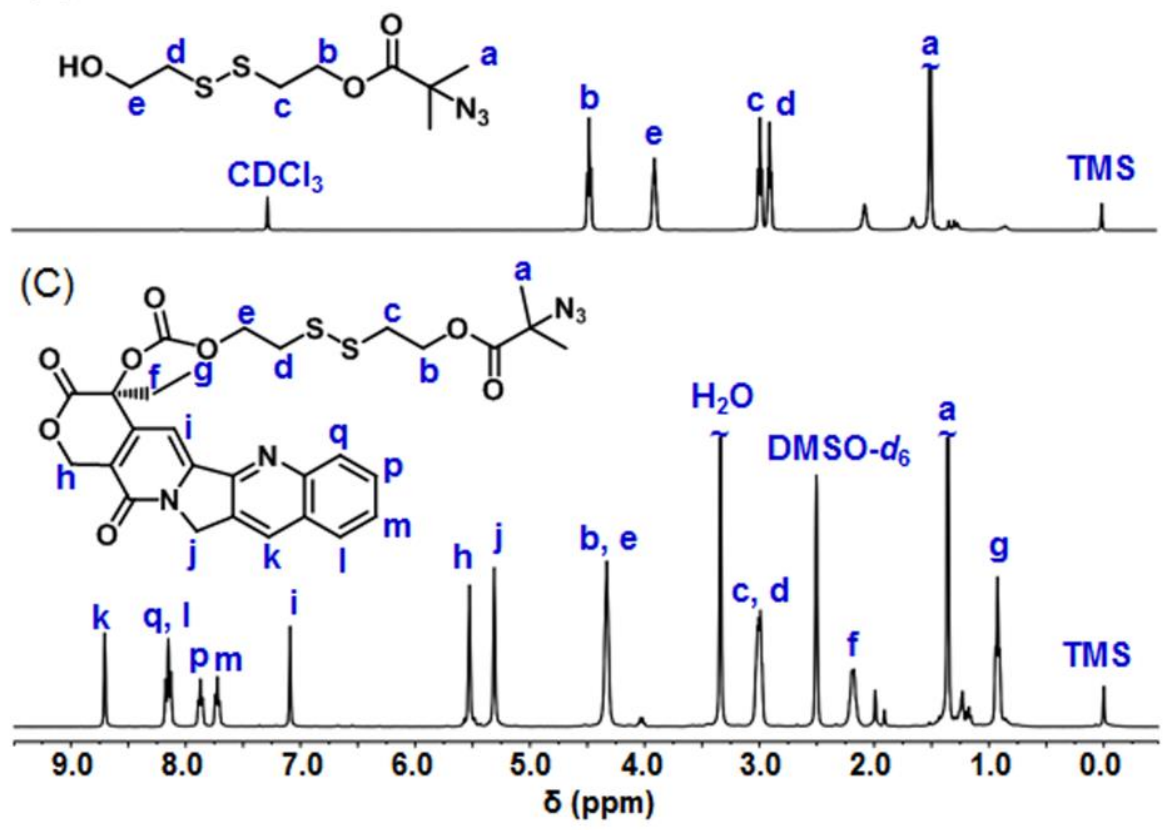

Figure S1. ${ }^{1} \mathrm{H}$ NMR spectra of (A) HO-ss-Br, (B) HO-ss- $\mathrm{N}_{3}$ in $\mathrm{CDCl}_{3}$ and (C) CPT-ss- $\mathrm{N}_{3}$ in DMSO- $d_{6}$.

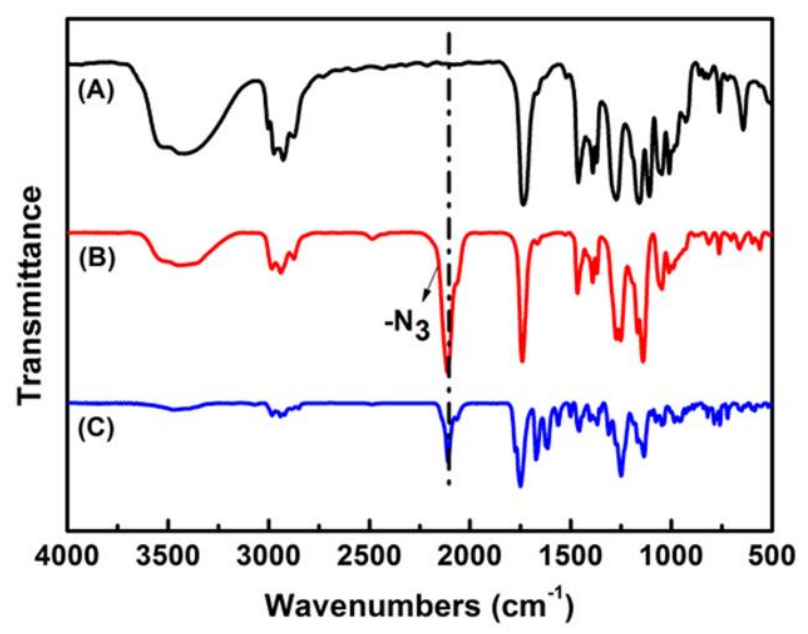

Figure S2. FT-IR spectra of (A) HO-ss-Br, (B) HO-ss- $\mathrm{N}_{3}$ and (C) CPT-ss- $\mathrm{N}_{3}$. 


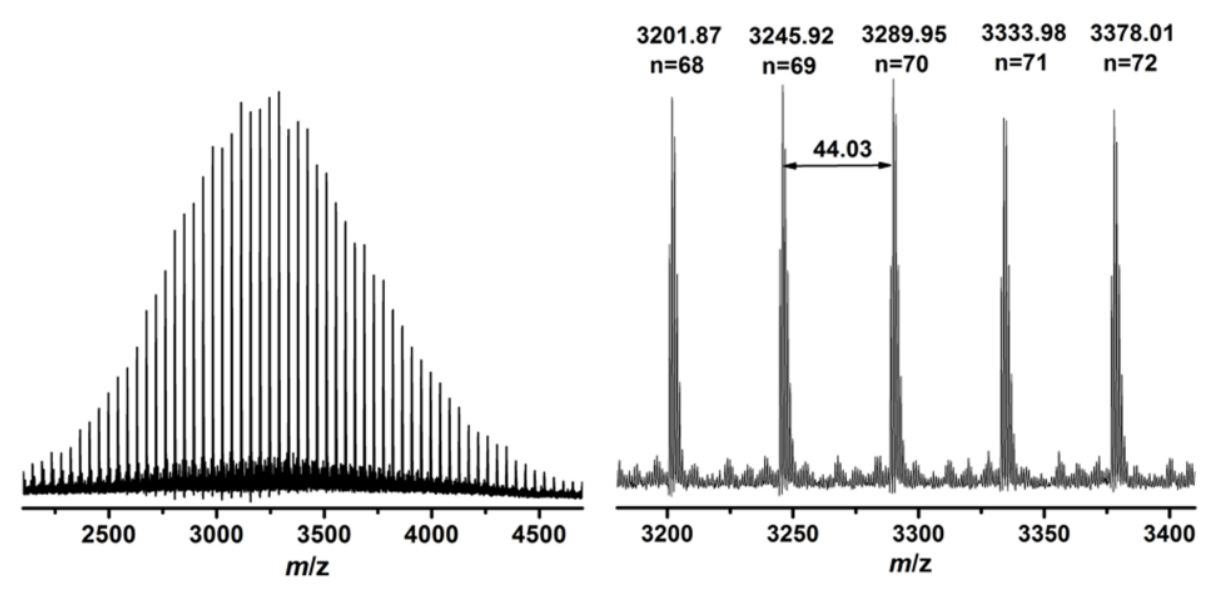

$$
\begin{aligned}
& \bar{M}_{\mathrm{n}}=(\mathrm{OH})+(\mathrm{SAE})+(\text { Monomer units }) \times \mathrm{n}+\mathrm{Na}^{+} \\
& \bar{M}_{\mathrm{n}}=17.03+168.07+44.03 \times \mathrm{n}+22.99 \\
& \begin{array}{lllll}
3201.87 & 3245.92 & 3289.95 & 3333.98 & 3378.01
\end{array} \\
& \mathrm{n}=68 \quad \mathrm{n}=69 \quad \mathrm{n}=70 \quad \mathrm{n}=71 \quad \mathrm{n}=72
\end{aligned}
$$

Figure S3. MALDI-TOF MS spectrum of SAE-PEG-OH.

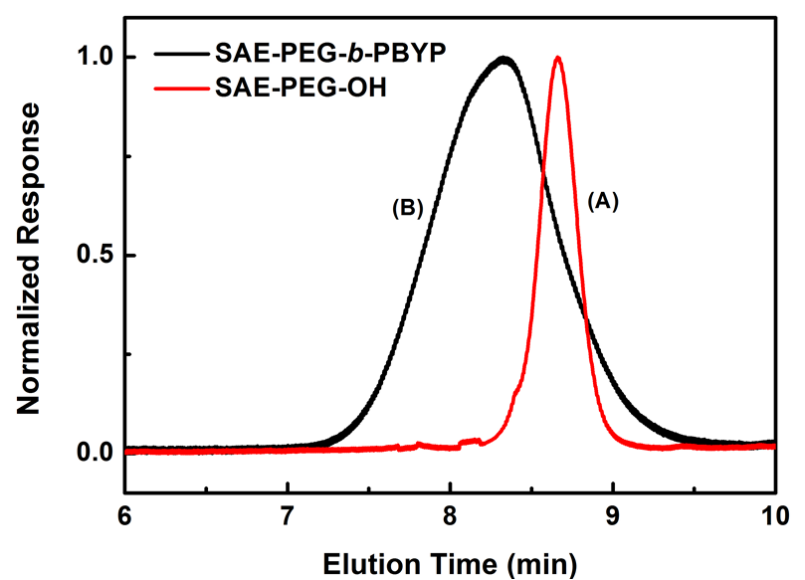

Figure S4. GPC curves of (A) SAE-PEG-OH ( $\left.\bar{M}_{\mathrm{n}}=3400 \mathrm{~g} \mathrm{~mol}^{-1}, \mathrm{PDI}=1.22\right)$ and (B) SAE-PEG- $b$-PBYP51 $\left(\bar{M}_{\mathrm{n}}=10500 \mathrm{~g} \mathrm{~mol}^{-1}, \mathrm{PDI}=1.49\right)$ in DMF. 


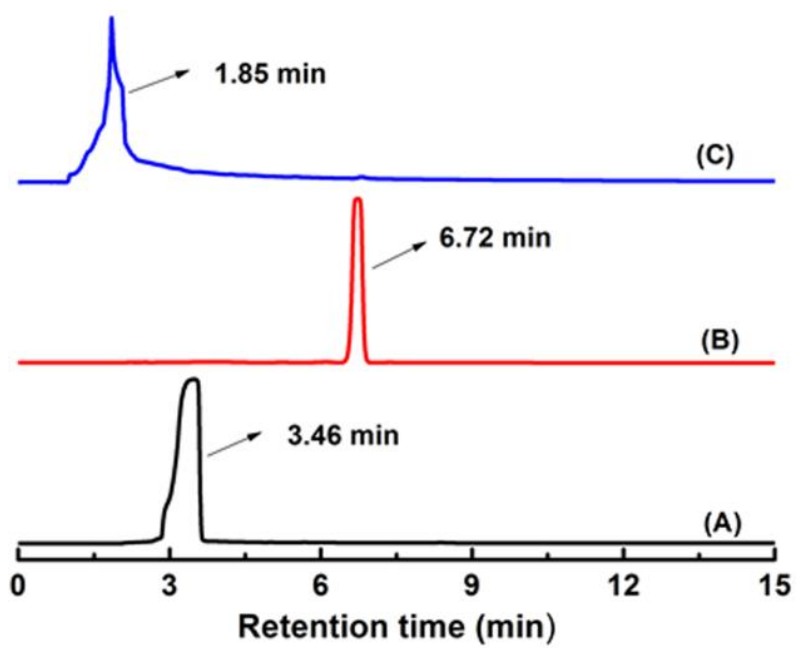

Figure S5. HPLC analyses results of (A) free CPT, (B) CPT- $s s-\mathrm{N}_{3}$ and (C) SAE-PEG- $b$-PBYP $51-s s-C P T$. HPLC analyses were performed with acetonitrile-water $(75 / 25, v / v)$ as the mobile phase at $30{ }^{\circ} \mathrm{C}$ with a flow rate of 1.0 $\mathrm{mL} \min ^{-1}$.

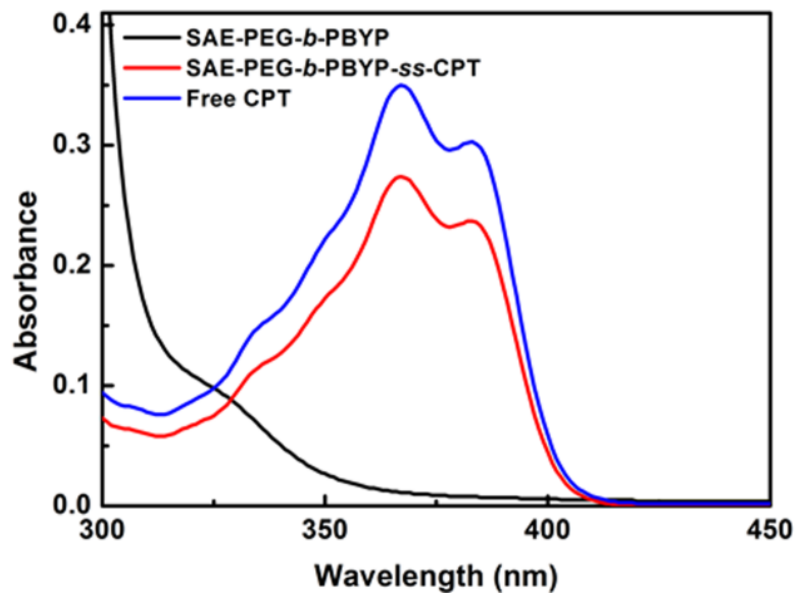

Figure S6. UV-vis spectra of free CPT, SAE-PEG- $b$-PBYP $51-s s-C P T$ and SAE-PEG- $b$-PBYP 51 . 


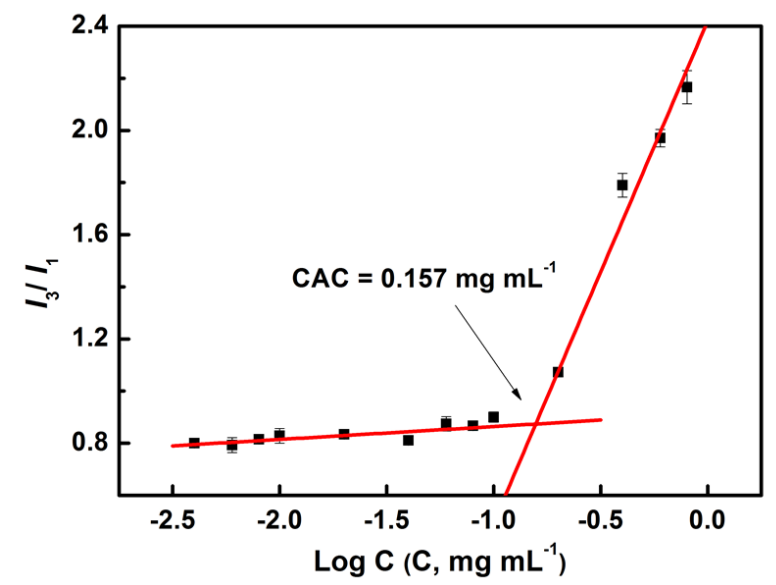

Figure S7. Intensity ratios $\left(I_{3} / I_{1}\right)$ in fluorescence emission spectra of pyrene as a function of logarithm concentration of SAE-PEG- $b$-PBYP $51-s s-\mathrm{CPT}$ in aqueous solution.

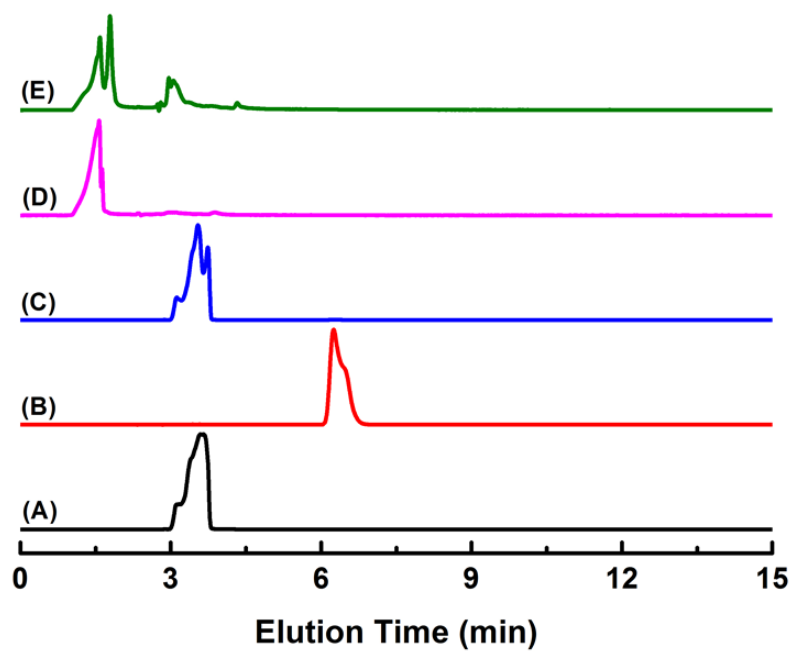

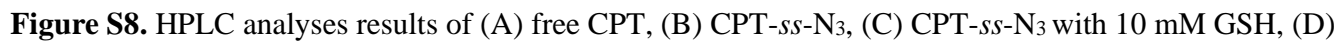
SAE-PEG- $b$-PBYP ${ }_{51}-s s-C P T$ and (E) SAE-PEG- $b$-PBYP ${ }_{51}-s s$-CPT with $10 \mathrm{mM} \mathrm{GSH}$. HPLC analyses were performed with acetonitrile-water $(75 / 25, v / v)$ as the mobile phase at $30{ }^{\circ} \mathrm{C}$ with a flow rate of $1.0 \mathrm{~mL} \mathrm{~min}^{-1}$.

\section{References}

S1. Zhang, S. Y.; Li, A.; Zou, J.; Lin, L. Y.; Wooley, K. L. Facile Synthesis of Clickable, Water-Soluble and Degradable Polyphosphoesters. ACS Macro Lett. 2012, 1, 328-333.

S2. Zhang, Q. Q.; He, J. L.; Zhang, M. Z.; Ni, P. H. A Polyphosphoester-Conjugated Camptothecin Prodrug with Disulfide Linkage for Potent Reduction-Triggered Drug Delivery. J. Mater. Chem. B 
$\mathbf{2 0 1 5}, 3,4922-4932$.

S3. Wilhelm, M.; Zhao, C. L.; Wang, Y. C.; Xu, R. L.; Winnik, M. A. Poly(styrene ethylene oxide) Block Copolymer Micelle Formation in Water A Fluorescence Probe Study. Macromolecules 1991, $24,1033-1040$.

S4. Zhou, J. C.; Zhuang, D. Q.; Yuan, X. F.; Jiang, M.; Zhang, Y. X. Association of Fluorocarbon and Hydrocarbon End-Capped Poly(ethylene glycol)s: NMR and Fluorescence Studies. Langmuir 2000, 16, 9653-9661. 